Community Participation at the Basic Education Level in Wakatobi Regency

\author{
Edy Karno ${ }^{1}$ \& Syahrul ${ }^{2}$ \\ ${ }^{1}$ Fakultas Keguruan dan Ilmu Pendidikan Universitas Halu Oleo \\ Email: edykarno72@gmail.com \\ ${ }^{2}$ Fakultas Tarbiyah dan Ilmu Keguruan IAIN Kendari \\ Email: syahrul.stain@gmail.com
}

\begin{abstract}
Abstrak
Artikel ini bertujuan memberikan gambaran tentang partisipasi masyarakat dalam pendidikan di Kabupaten Wakatobi. Aspek-aspek yang didalami antara lain: angka partisipasi murni pada tingkat pendidikan dasar, angka melek huruf penduduk usia 15 tahun ke atas, dan rata-rata lama sekolah penduduk usia 15 tahun ke atas. Kajian ini menggunakan pendekatan kualitatif, di mana studi dokumen menjadi teknik utama dalam pengumpulan data. Dokumen yang dikaji adalah arsip Dinas Pendidikan dan Kebudayaan, juga Badan Pusat Statistik Kabupaten Wakatobi. Analisis data dilakukan melalui tahapan pengumpulan data, reduksi data, penyajian data, dan penarikan kesimpulan. Hasil penelitian menunjukkan bahwa: 1) Angka Partisipasi Sekolah (APS) SD lebih dari 95 persen dan APSSMP lebih dari 76,15 persen. Hal ini menunjukkan bahwa Wajib Belajar 6 tahun yang didukung pembangunan infrastruktur sekolah dan diteruskan dengan Wajib Belajar 9 tahun adalah program sektor pendidikan yang diakui cukup sukses. Dengan kata lain, program wajib belajar dikatakan berhasil. 2) Angka melek huruf terlihat pada proporsi kepemilikan ijazah berdasarkan jenis kelamin. Dimana jenjang SD sederajat dan diploma ke atas, proporsi penduduk perempuan yang berijazah cenderung lebih tinggi dibandingkan penduduk laki-laki. Sedangkan pada jenjang SMP sederajat dan SMA sederajat proporsi penduduk laki-laki yang berijazah cenderung lebih tinggi dibandingkan penduduk perempuan. 3) selama periode 2010-2016, rata-rata lama sekolah di Kabupaten Wakatobi mengalami peningkatan dari tahun 2010 sebesar 6,18 tahun, di tahun 2016 menjadi 7,70 tahun.
\end{abstract}

Kata Kunci: Partisipasi Masyarakat, Pendidikan, Kebijakan 


\title{
Community Participation at the Basic Education Level in Wakatobi Regency
}

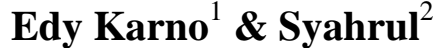 \\ ${ }^{1}$ Faculty of Teacher Training and Education of Halu Oleo University \\ Email: edykarno72@gmail.com \\ ${ }^{2}$ Faculty of Tarbiyah and Teacher Training \\ Email: syahrul.stain@gmail.com
}

\begin{abstract}
This article aims to provide an overview of community participation in education in Wakatobi District. The aspects explored include: pure enrollment rates at primary education level, literacy rates of people aged 15 years and over, and average length of schooling of residents aged 15 years and over. This study uses a qualitative approach, in which document study becomes the main technique in data collection. The document examined is the archive of the Education and Culture Office, as well as the Wakatobi Regency Central Statistics Agency. Data analysis is carried out through the stages of data collection, data reduction, data presentation, and drawing conclusions. The results showed that: 1) Elementary School Participation Rate (APS) was more than 95 percent and APSSMP was more than 76.15 percent. This shows that the 6-year Compulsory Education supported by school infrastructure development and continued with the 9-year Compulsory Education is an education sector program that is recognized as quite successful. In other words, compulsory learning programs are said to be successful. 2) Literacy rates are seen in the proportion of diploma ownership by sex. Where elementary school level is equal and diploma and above, the proportion of women with a diploma tends to be higher than the male population. While at the level of junior high school and senior high school, the proportion of the male population with a diploma tends to be higher than the female population. 3) during the 2010-2016 period, the average length of schooling in Wakatobi District had increased from 2010 by 6.18 years, in 2016 to 7.70 years.
\end{abstract}

Keywords: Community Participation, Education, Policy 


\section{Introduction}

Conceptually, education is a vehicle for the intellectual life of the nation as mandated by the Undang-Undang Dasar Tahun $1945^{1}$. Therefore, true education has a direct connection with the wider community. As a state, education management is carried out by the state apparatus, through the ministry of education and other ministries that organize education. Even so, the practice of managing national education is not only a state monopoly, but it gives a space for community participation $^{2}$.

The community can show their contribution in school management in the form of: material participation, thought participation, personnel participation, and moral participation. This is related to the condition of the community where educational institutions are located. So that the community can determine in what segment their involvement in school management.

Studies on community participation in education show variations, among others: in the school infrastructure improvement program $^{3}$, community learning activities center programs ${ }^{4}$, management of community participation in schools in remote areas ${ }^{5}$, the principal's strategy in increasing community participation ${ }^{6}$, and community participation in 9 -year education in border areas 7 .

1 Fahrudi, E. Z., \& Wiratmoko, D. (2016). Peran Pendidikan Sebagai Pondasi Penumbuhan Karakter Bangsa In-Donesia.

2 Sagala, H. S. (2008). Dukungan dan Partisipasi Masyarakat dalam Penyelenggaraan Pendidikan Khususnya di Sekolah. Generasi Kampus, 1(2).

${ }^{3}$ Chusnah, U. (2008). Evaluasi partisipasi masyarakat dalam pelaksanaan program peningkatan kualitas sarana prasarana pendidikan di SMA Negeri 1 Surakarta (Doctoral dissertation, Program Pasca Sarjana Universitas Diponegoro).

4 Hermawan, Y., \& Suryono, Y. (2016). Partisipasi masyarakat dalam penyelenggaraan program-program pusat kegiatan belajar masyarakat Ngudi Kapinteran. JPPM (Jurnal Pendidikan dan Pemberdayaan Masyarakat), 3(1), 97108.

5 Wibowo, A. (2015). Manajemen Partisipasi Masyarakat dalam Keterlaksanaan Pendidikan di Sekolah Daerah Terpencil (Studi Multisitus pada SDN Panikel 02 dan SDN Ujunggagak 03, Kampung Laut, Kabupaten Cilacap). DISERTASI dan TESIS Program Pascasarjana UM.

${ }^{6}$ Fauziyati, W. R. A. (2018). Strategi Kepala Sekolah Untuk Meningkatkan Partisipasi Masyarakat Dalam Pendidikan Menuju Generasi Maju Indonesia. QALAMUNA: Jurnal Pendidikan, Sosial, dan Agama, 10(01).

${ }^{7}$ Bunau, E., Sada, C., Salem, L., \& Hanye, P. (2011). Aksesibilitas dan Partisipasi Masyarakat Dalam Pendidikan Dasar 9 Tahun di daerah perbatasan 
Based on these studies, it is illustrated that the general public already has an awareness of their relationship with schooling, so that they can actively support the progress of the school. However, other studies show that people in the regions certainly still need encouragement and assistance to participate in the administration of education.

Community participation in education in Wakatobi Regency is interesting to note. This is related to several facts, that according to records from the Wakatobi Regency Education and Culture Office, development in the field of education has increased significantly in terms of the number of schools, the number of students, and the number of teachers at each level of education ${ }^{8}$. This fact can be used as an assumption that community participation in education in Wakatobi Regency tends to increase. This article tries to further explore community participation in education, especially at the level of basic education.

\section{Method}

This study uses a qualitative approach with descriptive techniques, where research data are collected in the form of percentage numbers, but analyzed qualitatively (not statistical analysis) ${ }^{9}$. The figures in the form of a percentage shown in the results of this study are data that has been available at the Office of Education and Culture, as well as the Central Statistics Agency of Wakatobi Regency. Therefore the main technique in collecting research data is document study. Data analysis was then performed using models from Miles and Huberman, namely: data reduction, data display, and data verification $^{10}$.

Kabupaten Sambas dan Sanggau Provinsi kalimantan Barat. Jurnal Cakrawala Kependidikan, 9(2).

${ }^{8}$ Halim, M., Karno, E., Ilham, M., \& Ili, L. (2018). Penyusunan Master Plan Indeks Pembangunan Manusia. Wakatobi: Badan Perencanaan, Penelitian dan Pengembangan Daerah Kabupaten Wakatobi.

${ }^{9}$ Sugiyono menjelaskan bahwa penelitian kualitatif tidak mengharamkan angka, terutama angka-angka yang hanya bersifat deskriptif. Lihat Sugiyono, P. Dr. (2010). Metode Penelitian Kuantitatif, Kualitatif, Dan R\&D. Bandung: CV Alfabeta. Beverly Hills.

${ }^{10}$ Miles, M. H., \& Huberman, A. M. A. 1984. Qualitative Data Analysis. 


\section{Results and Discussion}

\section{A. Pure Participation Rate in Basic Education in Wakatobi Regency}

Human resources play an important role in the progress of a nation, therefore it is necessary to strive to increase human resources for the achievement of development success. One effort to improve human resources is to improve the quality of education, both formal and non-formal. The emphasis of formal education is on improving the quality of education and expansion of basic education, besides it also increases learning opportunities at higher levels of education. While non-formal education is included to provide life skills to the community.

Non-formal education can also equip an attitude of independence that encourages the achievement of opportunities for entrepreneurship, which in the end is expected to be able to bring an increase in the standard of life and society in various aspects. Education is one of the factors that reflects the quality of human resources. The higher level of education they have, the easier it is for someone to follow the development of science and absorb technological advances. To improve the quality of education, adequate facilities and teaching staff are needed.

Development in the field of education is aimed at increasing population access to educational facilities, so that more residents are expected to be able to go to school. Educational development in Wakatobi District has shown considerable success. The 6-year compulsory education supported by the construction of school infrastructure and continued with the 9-year compulsory education is a recognized education sector program that is quite successful where the compulsory education program standard is said to be successful if the school participation rate (APS) is more than 95 percent and the junior high school APS is more than 76,15 percent.

Based on 2018 Ministry of Education and Culture data obtained data on the number of schools, teachers and graduates based on education levels in Wakatobi Regency as follows: 
Table 1

Pure Participation Rates by Gender and Education Level in Wakatobi Regency, 2016-2017

\begin{tabular}{|c|c|c|c|}
\hline Sex & Education Level & $\mathbf{2 0 1 6}$ & $\mathbf{2 0 1 7}$ \\
\hline Male & Elementary School & 93,62 & 98,21 \\
& Middle School & 75,65 & 84,64 \\
& High School & 54,13 & 61,04 \\
& University & 8,13 & - \\
\hline Female & Elementary School & 97,12 & 95,54 \\
& Middle School & 82,58 & 73,77 \\
& High School & 51,81 & 63,43 \\
& University & 21,02 & \\
\hline Pure & Elementary School & 95,29 & 96,88 \\
Participation & Middle School & 79,99 & 79,82 \\
Rates (APM) & High School & 53,08 & 62,34 \\
& University & 13,97 & \\
\hline
\end{tabular}

Source: National Social and Economic Survey, BPS

Pure Participation Rate (APM) is the proportion of the population in certain age groups of education who are still attending school to the population in that age group. The aim is to measure the absorption of the education system towards school-age population. So, APM shows how many school-age population are able to take advantage of educational facilities according to their level of education. If the APM $=100$, it means that all school-age children can attend school on time ${ }^{11}$. Based on table 1 above, Wakatobi still has homework related to education development, especially at the elementary school level (SD/SMP).

Rough Participation Rate (APK) and Pure Participation Rate (APM), are indicators of education development in Indonesia $^{12}$. Continual improvement in these two aspects will strengthen the foundation of national education, which is a sign of readiness to become an independent nation ${ }^{13}$. This is in line with the expectations

11 Amaliah, D. (2016). Pengaruh Partisipasi Pendidikan Terhadap Persentase Penduduk Miskin. Faktor Jurnal Ilmiah Kependidikan, 2(3).

12 Aristin, N. F. (2016). Faktor-faktor yang berpengaruh terhadap anak putus sekolah tingkat Sekolah Menengah Pertama (SMP) di Kecamatan Bondowoso. Jurnal Pendidikan Geografi, 20(1).

13 Ali, M. (2009). Pendidikan untuk pembangunan nasional: menuju bangsa Indonesia yang mandiri dan berdaya saing tinggi. Grasindo. 
of educational development in the context of the MDGs, achieving basic education for all ${ }^{14}$.

\section{B. Literacy rate is the percentage of population aged 15 years and over who can read and write Latin letters and or other letters = 95,29\%}

One component to calculate the magnitude of an area's human development index is the literacy rate, which is the percentage of the population aged 15 years and over who can read and write Latin letters and other letters. Literacy rates can be juxtaposed with school participation rates. That is, literacy rates are in line with school participation rates. Based on educational data released by BPS Wakatobi in 2017 are as follows:

Table 2

School Participation Rates

\begin{tabular}{|c|r|r|r|}
\hline Indicators & $\mathbf{2 0 1 4}$ & $\mathbf{2 0 1 5}$ & $\mathbf{2 0 1 6}$ \\
\hline School Participation Rates (\%) & & & \\
\hline $7-12$ & 100 & 100 & 98,27 \\
\hline $13-15$ & 97,64 & 98,11 & 97,14 \\
\hline $16-18$ & 97,78 & 79,59 & 96,15 \\
\hline $19-24$ & 18,36 & 21,88 & 21,74 \\
\hline
\end{tabular}

Source: Wakatobi in Numbers, 2017

Table 2 above shows that School Participation rates are based on the proportion of children who attend school in a particular school age group. School Participation Rate (APS) of children aged 7 to 12 years or at the elementary school level, in 2014 and 2015 was at 100 percent, decreased in 2016 to 98.27 percent. Which means 98.27 percent of children aged 7 to 12 years get education. Almost the same thing also happened in the age group of 13 to 15 years, in 2016 amounting to 97.14 percent which means that 98.11 children aged 13 to 15 years of education. This shows that the 9-year compulsory education program implemented by the government has been sufficiently implemented in Wakatobi Regency. However, it is

14 Sulistyastuti, D. R. (2007). PEMBANGUNAN PENDIDIKAN DAN MDGs DI INDONESIA Sebuah Refleksi Kritis. Jurnal Kependudukan Indonesia, 2(2), 19-44. 
different with residents aged 16 to 24 years. During the last two years the percentage of people who attend school at that age level has decreased, which was originally 21.88 percent in 2015 to 21.74 percent in 2016.

Table 3 shows that the age of 10 years and over who have never / never attended school is around 6.21 percent and those who have not / have not completed primary school education are relatively large at 20.51 percent. While those who succeeded in completing their education up to elementary school reached 35.63 percent. That means that around 6.21 percent of the population of Wakatobi Regency has not optimally felt the benefits of development in education as announced by the government in the 9-Year Compulsory Education Program. This proportion is even decreasing for higher levels of education. There are still a few people who are able to complete their education up to diploma level and above, which is only around $8.99 \%$.

Table 3

Population Aged 10 Years and Over According to Status School and Gender, Wakatobi 2016

\begin{tabular}{|l|c|c|c|}
\hline \multicolumn{1}{|c|}{ Status School } & Male & Female & Wakatobi \\
\hline Never Attended School & 1.61 & 4.60 & 6.21 \\
\hline Still in school & 12.67 & 12.55 & 25.21 \\
\hline - Elementary school & 5.17 & 4.37 & 9.54 \\
\hline - Middle School equivalent & 2.82 & 4.16 & 6.98 \\
\hline - High school equivalent & 3.41 & 2.43 & 5.84 \\
\hline - Diploma and above & 1.26 & 1.59 & 2.85 \\
\hline No School & 33.05 & 35.52 & 68.58 \\
\hline
\end{tabular}

Source: National Social and Economic Survey, BPS 2016

The total population in terms of sex, based on Table 4 below shows that at the elementary level and diploma and above, the proportion of female population with a certificate tends to be higher than the male population. While at the level of junior high school and senior high school the proportion of the male population with a diploma tends to be higher than the female population.

Table 4 
Population Age 10 Years and Over According to the Highest Diploma and Gender, Wakatobi 2016

\begin{tabular}{|l|r|r|r|}
\hline Status School & \multicolumn{1}{|c|}{ Male } & Female & Wakatobi \\
\hline Not yet in School & 1.61 & 4.60 & 6.21 \\
\hline Not Yet Finished of SD & 10.50 & 10.02 & 20.51 \\
\hline Elementary school equivalent & 16.21 & 19.42 & 35.63 \\
\hline Middle school equivalent & 5.35 & 5.06 & 10.41 \\
\hline High school equivalent & 9.44 & 8.20 & 17.64 \\
\hline Diploma and above & 4.22 & 5.39 & 9.61 \\
\hline
\end{tabular}

Source: National Social and Economic Survey, 2016

Literacy rates are an indicator of educational development in an area, which is also a component of the human development index. The higher the literacy rate or literacy skills, the higher the quality of human resources. People who can read and write are assumed to have the ability and skills because they can absorb information verbally and in writing ${ }^{15}$.

\section{The average length of schooling illustrates the number of years used by residents aged 15 years and over in undergoing formal education ( 7.70 years).}

The average number of years of schooling in Wakatobi Regency from 2010 to 2016 continues to increase. In 2010 to 2011, the average length of schooling in the population of Wakatobi Regency was still under 7 years, which was 6.18 years and increased to 6.85 in 2011, then continued to increase every year to 7.7 in 2016. This shows that in 2016, an average population of 25 years and over went to school for 7.7 years. This means that the average population of Wakatobi Regency can only undergo education up to grade 1 junior high school or drop out of school in grade 2 junior high. This condition illustrates the nine-year compulsory education program has not produced maximum results.

15 Jolianis, J., Del Rosa, Y., \& Dores, E. (2015). Pengaruh Angka Melek Huruf dan Angka Harapan Hidup terhadap Jumlah Penduduk Miskin di Propinsi Sumatera Barat. Pendidikan Ekonomi, 2(2), 29806. 
Table 5

Average Length of Schooling in Wakatobi, 2010-2016

\begin{tabular}{|c|c|}
\hline Years & Average Length of Schooling \\
\hline 2010 & 6,18 \\
\hline 2011 & 6,85 \\
\hline 2012 & 7,08 \\
\hline 2013 & 7,53 \\
\hline 2014 & 7,68 \\
\hline 2015 & 7,69 \\
\hline 2016 & 7,70 \\
\hline
\end{tabular}

Source: BPS Of Wakatobi Regency, 2017

Table 5 shows the development of the average length of schooling in Wakatobi District. During the 2010-2016 period, the average length of schooling in Wakatobi District increased from 2010 by 6.18 years, in 2016 to 7.70 years.

The Year of Conversion from Education completed is:

Elementary School

Middle School

High School

Diploma I

Diploma II

Diploma III

Bachelor/Diploma IV

Magister

Doktor

$$
\begin{aligned}
& =6 \text { years } \\
& =9 \text { years } \\
& =12 \text { years } \\
& =13 \text { years } \\
& =15 \text { years } \\
& =16 \text { years } \\
& =18 \text { years } \\
& =18 \text { years } \\
& =21 \text { years }
\end{aligned}
$$

Average Length of School is a component of the Human Development Index in Indonesia. This component describes the number of years used by residents aged 15 years and over in 
undergoing formal education. However, the average length of school does not have a significant relationship with poverty levels ${ }^{16}$.

\section{Conclusions and Recommendations}

Community participation in education at the level of basic education has increased, this is indicated by the Elementary School Participation Rate (APS) of more than 95 percent and APSSMP of more than 76.15 percent. This means that a 6-year compulsory education supported by school infrastructure development and continued with a 9-year compulsory education is a fairly successful education sector program. Likewise, the literacy rate, which is seen in the proportion of diploma ownership by sex. Where the level of elementary school is equal and diploma and above, the proportion of women with a diploma tends to be higher than the male population. While at the level of junior high school and senior high school, the proportion of the male population with a diploma tends to be higher than the female population. During the $2010-2016$ period, the average length of schooling in Wakatobi District increased from 6.18 years in 2010 , in 2016 to 7.70 years.

This article suggests the need for further investigation of the strategy of the local government in Wakatobi Regency in increasing community participation in education. In addition, research is needed about the relationship between literacy rates and average length of school and poverty rates in Wakatobi district.

${ }^{16}$ Kumalasari, M., \& POERWONO, D. (2011). Analisis Pertumbuhan Ekonomi, Angka Harapan Hidup, Angka Melek Huruf, Rata Rata Lama Sekolah, Pengeluaran Perkapita dan Jumlah Penduduk terhadap Tingkat Kemiskinan Di Jawa Tengah (Doctoral dissertation, Universitas Diponegoro). 


\section{References}

Ali, M. (2009). Pendidikan untuk pembangunan nasional: menuju bangsa Indonesia yang mandiri dan berdaya saing tinggi. Grasindo.

Amaliah, D. (2016). Pengaruh Partisipasi Pendidikan Terhadap Persentase Penduduk Miskin. Faktor Jurnal Ilmiah Kependidikan, 2(3).

Aristin, N. F. (2016). Faktor-faktor yang berpengaruh terhadap anak putus sekolah tingkat Sekolah Menengah Pertama (SMP) di Kecamatan Bondowoso. Jurnal Pendidikan Geografi, 20(1).

Bunau, E., Sada, C., Salem, L., \& Hanye, P. (2011). Aksesibilitas dan Partisipasi Masyarakat Dalam Pendidikan Dasar 9 Tahun di daerah perbatasan Kabupaten Sambas dan Sanggau Provinsi kalimantan Barat. Jurnal Cakrawala Kependidikan, 9(2).

Chusnah, U. (2008). Evaluasi partisipasi masyarakat dalam pelaksanaan program peningkatan kualitas sarana prasarana pendidikan di SMA Negeri 1 Surakarta (Doctoral dissertation, Program Pasca Sarjana Universitas Diponegoro).

Fahrudi, E. Z., \& Wiratmoko, D. (2016). Peran Pendidikan Sebagai Pondasi Penumbuhan Karakter Bangsa In-Donesia.

Fauziyati, W. R. A. (2018). Strategi Kepala Sekolah Untuk Meningkatkan Partisipasi Masyarakat Dalam Pendidikan Menuju Generasi Maju Indonesia. QALAMUNA: Jurnal Pendidikan, Sosial, dan Agama, 10(01).

Halim, M., Karno, E., Ilham, M., \& Ili, L. (2018). Penyusunan Master Plan Indeks Pembangunan Manusia. Wakatobi: Badan Perencanaan, Penelitian dan Pengembangan Daerah Kabupaten Wakatobi.

Hermawan, Y., \& Suryono, Y. (2016). Partisipasi masyarakat dalam penyelenggaraan program-program pusat kegiatan belajar masyarakat Ngudi Kapinteran. JPPM (Jurnal Pendidikan dan Pemberdayaan Masyarakat), 3(1), 97-108.

Jolianis, J., Del Rosa, Y., \& Dores, E. (2015). Pengaruh Angka Melek Huruf dan Angka Harapan Hidup terhadap Jumlah Penduduk Miskin di Propinsi Sumatera Barat. Pendidikan Ekonomi, 2(2), 29806.

Kumalasari, M., \& POERWONO, D. (2011). Analisis Pertumbuhan Ekonomi, Angka Harapan Hidup, Angka Melek Huruf, Rata 
Rata Lama Sekolah, Pengeluaran Perkapita dan Jumlah Penduduk terhadap Tingkat Kemiskinan Di Jawa Tengah (Doctoral dissertation, Universitas Diponegoro).

Miles, M. H., \& Huberman, A. M. A. 1984. Qualitative Data Analysis. Beverly Hills.

Sagala, H. S. (2008). Dukungan dan Partisipasi Masyarakat dalam Penyelenggaraan Pendidikan Khususnya di Sekolah. Generasi Kampus, 1(2).

Sugiyono, P. Dr. (2010). Metode Penelitian Kuantitatif, Kualitatif, Dan R\&D. Bandung: CV Alfabeta.

Sulistyastuti, D. R. (2007). Pembangunan Pendidikan dan MDGs di Indonesia Sebuah Refleksi Kritis. Jurnal Kependudukan Indonesia, 2(2), 19-44.

Wibowo, A. (2015). Manajemen Partisipasi Masyarakat dalam Keterlaksanaan Pendidikan di Sekolah Daerah Terpencil (Studi Multisitus pada SDN Panikel 02 dan SDN Ujunggagak 03, Kampung Laut, Kabupaten Cilacap). DISERTASI dan TESIS Program Pascasarjana UM.

Wiratno, B. (2016). Partisipasi Masyarakat dalam Pendidikan. Jurnal Pendidikan Ilmu Sosial, 26(1), 28-34. 